\title{
Udzielna prałatura kłajpedzka po wcieleniu Okręgu Kłajpedy do Rzeszy Niemieckiej w 1939 roku
}

\begin{abstract}
Abstrakt: Celem artykułu jest ukazanie stanu udzielnej prałatury kłajpedzkiej po wcieleniu Okręgu Kłajpedy do Rzeszy Niemieckiej w 1939 roku. Prałaturę tę ustanowiono w 1926 roku. Podporządkowano ją litewskiemu biskupowi urzędującemu w Telszach. Po 13 latach obszar ten włączono do Niemiec. Dość szybko jej administratorem ustanowiono biskupa warmińskiego Maksymiliana Kallera. W artykule zaprezentowano proces dostosowania się prałatury do nowych warunków politycznych. W tym celu przeanalizowano źródła archiwalne i literaturę pod kątem określenia statusu tej jednostki kościelnej oraz jej finansowania z funduszy państwowych. Dzięki temu zobrazowano nie tylko problematykę personalną w prałaturze czy też jej niekorzystne warunki materialne i finansowe, lecz także nieprzychylny stosunek Rzeszy Niemieckiej do Kościoła katolickiego.
\end{abstract}

Słowa kluczowe: Kościół katolicki w Trzeciej Rzeszy, Litwa, Okręg Kłajpedy, Prusy Wschodnie, Rzesza Niemiecka, udzielna prałatura kłajpedzka

Badania nad Okręgiem Kłajpedy od dawna cieszą się dość dużym zainteresowaniem historyków ${ }^{1}$. Dotychczas jednak nie opracowano monografii dotyczącej działalności Kościoła katolickiego na tym obszarze. Sporo informacji na ten temat

${ }^{1}$ Zob. zwłaszcza P. Łossowski: Kłajpeda kontra Memel. Problem Kłajpedy w latach 1918-1939_ 1945. Warszawa 2007; S. Mikulicz: Kłajpeda w polityce europejskiej 1918-1939. Warszawa 1976; J. TAu BER: Das Memelgebiet (1919-1945) in der deutschen und litauischen Historiografie nach 1945. „Nordost-Archiv. Zeitschrift für Regionalgeschichte” (Neue Folge) 2001, 10, s. 11-44. 
przytoczyli ks. Andrzej Kopiczko² i Arūnas Streikus ${ }^{3}$. Autorzy ci pobieżnie jednak potraktowali sytuację udzielnej prałatury kłajpedzkiej po aneksji Okręgu Kłajpedy do Rzeszy Niemieckiej w 1939 roku. Żeby uzupełnić te wiadomości, warto przeprowadzić analizę rzadko dotychczas wykorzystywanej dokumentacji dotyczącej tego kościelnego terytorium, którą zdeponowano w Bundesarchiv w Berlinie. Niniejszy artykuł ma na celu przede wszystkim prezentację procesu dostosowania się prałatury kłajpedzkiej do nowych warunków politycznych. Należy zaznaczyć, że zostanie w nim pominięta martyrologia mieszkańców tego obszaru, a także kwestie inwigilacji duchowieństwa i wiernych przez władze hitlerowskie. Zagadnienia te zasługują bowiem na odrębne studium.

\section{Status udzielnej prałatury kłajpedzkiej w nowych graniach państwowych}

Po pierwszej wojnie światowej, wskutek ratyfikacji traktatu wersalskiego, Okręg Kłajpedy został wyłączony z granic Republiki Weimarskiej i powierzony pod nadzór Ligi Narodów. W 1923 roku Litwini wywołali powstanie na tym obszarze, inspirowane przez rząd w Kownie, a rok później podpisali w Paryżu Konwencję Kłajpedzką. Zgodnie z jej postanowieniami od 1925 roku Okręg Kłajpedy stał się integralną częścią Litwy na prawach autonomii ${ }^{4}$. Papież Pius XI w bulli Lituanorum gente z 4 kwietnia 1926 roku przeprowadził z kolei cyrkupskrypcję Kościoła katolickiego na Litwie, ustanawiając na terenie Nadniemna udzielną prałaturę kłajpedzką z biskupem telszańskim na czele. W jej skład weszły dotychczasowe parafie diecezji warmińskiej usytuowane w Kłajpedzie, Robkojen, Szyłokarczmie oraz parafia misyjna w Wischwill ${ }^{5}$.

Po niespełna 13 latach niespodziewane przemiany geopolityczne zapoczątkowały nowy etap funkcjonowania udzielnej prałatury kłajpedzkiej. Tuż bowiem przed wybuchem drugiej wojny światowej, 23 marca 1939 roku, Niemcy narzuciły

2 A. Kopiczко: Die katholische Kirche in Memelland (1923-1939). „Acta Historica Universitatis Klaipedensis" 2015, 30, s. 101-125.

3 A. STREIKus: Die Integration der memelländischen Katholiken in die Kirchenprovinz Litauen 1926-1939. „Annaberger Annalen” 2013, 21, s. 100-127.

${ }^{4}$ S. Mikulicz: Kłajpeda w polityce europejskiej..., s. 44, 72-73, 115-116; J. Ochmański: Historia Litwy. Wrocław 1982, s. 318-319.

${ }^{5}$ A. Kopiczko: Duchowieństwo katolickie diecezji warmińskiej w latach 1821-1945. Cz. 1: Studium prozopograficzne. Olsztyn 2004, s. 246-247; IDEm: Die katholische Kirche in Memelland..., s. 105. W 1932 roku utworzono samodzielną placówkę duszpasterską w Pogegen; zob. A. KopiczKo: Die katholische Kirche in Memelland..., s. 110. 
Litwie podpisanie układu, który sankcjonował przekazanie Okręgu Kłajpedy na rzecz Trzeciej Rzeszy ${ }^{6}$. Kilka dni później, 7 kwietnia tego roku, w kurii diecezjalnej w Telszach odbyła się narada na temat skutków zawartego układu. Uczestniczył w niej dziekan kłajpedzki ks. kanonik Albert Dannelautzki. Potwierdzono na niej, że księża oddelegowani z diecezji telszańskiej do pracy w udzielnej prałaturze kłajpedzkiej pozostaną nadal pod jurysdykcją biskupa telszańskiego. Otrzymali również zgodę na dalszą pracę na tym obszarze. Dziekan kłajpedzki nie mógł jednak dłużej troszczyć się o ich uposażenie, ponieważ Dyrektoriat Okręgu Kłajpedy na polecenie Rzeszy Niemieckiej zaprzestał finansowania litewskiego duchowieństwa. $\mathrm{Z}$ pomocą przyszedł mu rząd litewski, któremu zależało na obecności litewskich księży w dawnym Okręgu Kłajpedy. Przyznał on pensję pięciu duchownym, którzy zdecydowali się pozostać na tym terenie ${ }^{7}$.

Po aneksji Okręgu Kłajpedy do Niemiec udzielna prałatura kłajpedzka nadal podlegała jurysdykcji biskupa telszańskiego Justinasa Staugaitisa. Ten jednakże przekazał administrowanie tym obszarem ks. dziekanowi A. Dannelautzkiemu8. Arūnas Streikus, który badał korespondencję bp. J. Staugaitisa, zauważył, że nie wiązał on większych nadziei na umacnianie wpływów litewskich w prałaturze. Dalsze administrowanie tym obszarem wydawało mu się ciężarem, który możliwie najszybciej chciał z siebie zrzucić 9 .

Pod naciskiem Trzeciej Rzeszy Stolica Apostolska dekretem Kongregacji Konsystorialnej z 10 czerwca 1939 roku powierzyła zarządzanie udzielną prałaturą kłajpedzką biskupowi warmińskiemu Maksymilianowi Kallerowi, mianując go jej administratorem apostolskim. Tym samym zwolniono z powyższych obowiązków bp. J. Staugaitisa. Oficjalną informację w tej sprawie Nuncjatura Apostolska w Berlinie przekazała Ministerstwu Spraw Zagranicznych Niemiec 30 czerwca tego roku ${ }^{10}$.

Ustanowienie bp. M. Kallera administratorem udzielnej prałatury kłajpedzkiej „ad nutum Sanctae Sedis” tymczasowo zadowalało rząd Trzeciej Rzeszy. Minister spraw kościelnych Hanns Kerrl za pośrednictwem Ministerstwa Spraw Zagranicznych Niemiec informował jednak Nuncjaturę Apostolską w Berlinie, że Niemcy nie zgadzają się w dłuższej perspektywie na pozostawienie takiego stanu prawnego. Sprzeciwiają się także, aby podobny precedens wydarzył się w przyszłości ${ }^{11}$. Władze

${ }^{6}$ A. Kopiczko: Duchowieństwo katolickie diecezji warmińskiej w latach 1821-1945. Cz. 1..., s. 248; S. Mikulicz: Kłajpeda w polityce europejskiej..., s. 246-247; J. Ochмańsкi: Historia Litwy..., s. 343.

7 A. Streikus: Die Integration der memelländischen Katholiken..., s. 125.

${ }^{8}$ Bundesarchiv Berlin (dalej: BAB), R 5101/21808, k. 73.

9 A. Streikus: Die Integration der memelländischen Katholiken..., s. 126.

${ }_{10}$ A. Корісzко: Duchowieństwo katolickie diecezji warmińskiej w latach 1821-1945. Cz. 1..., s. 248.

${ }_{11}$ BAB, R 5101/21808, k. 60; zob. również A. Kорісzко: Duchowieństwo katolickie diecezji warmińskiej w latach 1821-1945. Cz. 1..., s. 249. 
hitlerowskie uważały bowiem, że kościelny status Okręgu Kłajpedy, nadany w 1926 roku, stał w sprzeczności z niemiecką racją stanu. Ich zdaniem, wymierzony był również przeciwko duchowieństwu katolickiemu. Rząd w Berlinie podkreślał, że umacnianie więzi z Rzeszą Niemiecką przyniosło duszpasterzom tego wyznania wymierne korzyści. Władze państwowe, z pominięciem litery prawa, wyraziły bowiem gotowość zrównania wynagrodzeń księży pracujących $\mathrm{w}$ prałaturze $\mathrm{z}$ duchowieństwem pruskim ${ }^{12}$. Warto nadmienić, że bp M. Kaller objął rządy w udzielnej prałaturze kłajpedzkiej 16 lipca 1939 roku $^{13}$.

Przed aneksją we wszystkich parafiach Okręgu Kłajpedy znacznie wzrosła liczba litewskojęzycznej ludności ${ }^{14}$. Ks. A. Dannelautzki dostrzegał konieczność otoczenia jej opieką pastoralną. Zresztą uważał, że stanowi ona dla Rzeszy Niemieckiej tanią siłę roboczą. W związku z tym zabiegał nie tylko o możliwość pozostawienia księży litewskich w parafiach Nadniemna, lecz także ściągania dodatkowych z Litwy. Zastrzegał przy tym, że będzie czuwał nad ich lojalnością względem Niemiec ${ }^{15}$.

\section{Sytuacja materialno-prawna placówek duszpasterskich}

Jeśli chodzi o zarządzanie majątkiem kościelnym, parafie udzielnej prałatury kłajpedzkiej miały obowiązek stosowania się do ustawy pruskiej z 20 czerwca 1875 roku. Zgodnie z jej treścią, warunkiem uznania przez władze państwowe osobowości prawnej takich wspólnot było powołanie zarządu kościelnego oraz wyłonienie przedstawicieli parafii. W czasach istnienia Okręgu Kłajpedy zaprzestano przeprowadzania kolejnych wyborów do tych gremiów. W katolickiej wspólnocie duszpasterskiej w Pogegen nigdy nie wyłoniono zarządu kościelnego. Z kolei ks. dziekan A. Dannelautzki jeszcze w 1938 roku zwrócił się do Dyrektoriatu Okręgu Kłajpedy o zgodę na odroczenie wyboru zarządu kościelnego parafii w Kłajpedzie i wytypowanie jej przedstawicieli. Dyrektoriat przychylił się do tego postulatu i przedłużył kadencję urzędowania dotychczasowych gremiów do $1940 \mathrm{roku}^{16}$.

W imieniu biskupa warmińskiego rozmowy z księżmi udzielnej prałatury kłajpedzkiej przeprowadził 19 lipca 1939 roku wikariusz generalny diecezji warmińskiej ks. Alois Marquardt. Proboszczowie tamtejszych parafii oznajmili, że nie są w stanie zorganizować tego roku wyborów do zarządu kościelnego i wyłonić przedstawicieli

${ }^{12}$ BAB, R 5101/21808, k. 60v.

13 A. Корісzко: Duchowieństwo katolickie diecezji warmińskiej w latach 1821-1945. Cz. 1..., s. 248.

${ }^{14}$ BAB, R 5101/21808, k. 68.

${ }^{15}$ Ibidem, k. 73.

${ }^{16}$ Ibidem, k. 68. 
wspólnot parafialnych. Z tego względu diecezja zabiegała u władz państwowych o prolongatę kadencji wcześniej zatwierdzonych gremiów parafialnych w Kłajpedzie, Robkojen, Szyłokarczmie i Wischwill do 1 października 1940 roku. Wspólnotę kościelną w Pogegen miał reprezentować zarząd kościelny w Szyłokarczmie ${ }^{17}$. Minister Spraw Kościelnych zaaprobował tę prośbę ${ }^{18}$.

Parafie udzielnej prałatury kłajpedzkiej zmagały się przede wszystkim z problemami wynikającymi z jej usytuowania na obszarze diaspory. Wyróżniała je również struktura narodowościowa duchowieństwa oraz wiernych. W maju 1939 roku ks. dziekan A. Dannelautzki informował władze państwowe, że parafia w Kłajpedzie obejmowała cały powiat o tej nazwie, a zatem 282 miejscowości oraz majątki. Duchowni mieszkali przy kościele parafialnym w Kłajpedzie. Dwie niewielkie świątynie znajdowały się również w Plicken i Prökuls. Dwa razy w ciągu miesiąca celebrowano w nich msze św. We wszystkich miejscowościach mieszkała katolicka ludność, która podejmowała najmniej opłacane prace. Pochodziła ona zazwyczaj z Litwy. Władze państwowe nie wydalały jej ze względu na odczuwany brak pracowników. Na terenach wiejskich odnotowano wówczas ok. 600 dzieci tego wyznania w wieku szkolnym. Niemało problemów sprawiało kłajpedzkiemu dziekanowi zorganizowanie dla nich lekcji religii, ponieważ uczęszczały one do 54 szkół ewangelickich ${ }^{19}$.

W parafiach udzielnej prałatury kłajpedzkiej dotkliwie odczuwano brak środków finansowych. Biskup M. Kaller z ubolewaniem konstatował, że przez długie lata nie wykonywano żadnych prac remontowych przy plebanii w Robkojen. Z tego względu znajdowała się ona w opłakanym stanie. Biskup podkreślał, że miejscowa parafia składała się w większości z biednych ludzi ${ }^{20}$. O skali jej potrzeb materialnych świadczył program prac budowlano-remontowych, opracowany w marcu 1941 roku. Dotyczył on remontu wnętrza plebanii, odświeżenia jej elewacji, remontu starej szkoły, budynków gospodarczych, organów, a także wykopania studni ${ }^{21}$. Parafia zwracała się $\mathrm{z}$ prośbą o dofinansowanie tego przedsięwzięcia w wysokości 6500 marek do Bonifatiuswerk (pol. Dzieło św. Bonifacego) w Paderborn ${ }^{22}$.

Po wcieleniu Okręgu Kłajpedy do Rzeszy Niemieckiej bank, w którym zaciągnięto pożyczkę pod budowę kościoła i plebanii w Pogegen, uruchomił procedurę windykacji. Zabezpieczeniem kredytu była hipoteka pod nieruchomość ks. Nikodemasa Petkusa, znajdująca się w Kłajpedzie. Kiedy udzielna prałatura kłajpedzka

${ }^{17}$ Ibidem, k. 68-68v.

${ }_{18}$ Ibidem, k. 69.

19 Ibidem, k. 57-57v.

${ }^{20}$ Archiwum Zarządu Generalnego Stowarzyszenia św. Bonifacego w Paderborn (dalej: AP), Teczka: Robkojen, biskup Kaller do Zarządu Generalnego Stowarzyszenia św. Bonifacego w Paderborn, 22 III 1941.

${ }^{21}$ AP, Teczka: Robkojen, ks. Bilitewski do kurii we Fromborku, 19 III 1941.

${ }^{22}$ Ibidem, biskup Kaller do Zarządu Stowarzyszenia św. Bonifacego w Paderborn, 22 III 1941. 
znalazła się pod jurysdykcją biskupa warmińskiego, diecezja warmińska zaczęła spłacać odsetki od tego kredytu. 19 stycznia 1940 roku ks. N. Petkus udał się do biskupa warmińskiego, zabiegając o 6960 marek, aby zwolnić nieruchomość z zadłużenia hipotecznego. Ponieważ władze diecezjalne już wcześniej podjęły decyzję o spłacie tych należności, biskup warmiński wyszedł naprzeciw oczekiwaniom tego duchownego. Zgodnie z przekazaną przez niego informacją, wartość długu wynosiła 7177,39 marek, z czego końcówkę tej sumy, czyli 217,39 przekazała mu Kasa Diecezjalna we Fromborku. Rządca diecezji przedłożył prośbę ks. N. Petkusa Dziełu dla Diaspory (Diasporawerk), czyli instytucji diecezjalnej powołanej w miejsce zlikwidowanego Stowarzyszenia św. Bonifacego i Wojciecha. Monitorowało ono sytuację placówek katolickich w diasporze diecezji warmińskiej ${ }^{23}$. Ostatecznie z tego źródła otrzymano 3 tys. marek ${ }^{24}$, natomiast 4100 marek z Bonifatiuswerk w Paderborn ${ }^{25}$. W lutym 1941 roku zamierzano przeprowadzić remont kościoła i plebanii w Pogegen. Kosztorys prac świątyni opiewał na 3926,95 marek, natomiast plebanii - na 1131,10 marek. Przedsięwzięcie miało objąć malowanie elewacji plebanii, okien w górnej kondygnacji i ogrodzenia placu parafialnego przy ulicy. Do tego czasu nie zdołano zakończyć prac budowlanych we wnętrzu miejscowego kościoła. Zaplanowano zatem malowanie jego ścian i naprawę dachu ${ }^{26}$. Zwieńczenia tej inwestycji zażądała zresztą miejscowa policja. W sumie na ten cel otrzymano 5 tys. marek - zarówno z diecezjalnego Dzieła dla Diaspory, jak i za pośrednictwem Bonifatiuswerk ${ }^{27}$. Na pokrycie długów remontowo-budowlanych instytucje te przekazały w połowie 1941 roku kolejne 700 marek $^{28}$.

W marcu 1940 roku parafia w Szyłokarczmie liczyła ok. 2400 katolików. Na jej obszarze mieszkało 33 tys. protestantów. W tym czasie przybywało niemieckojęzycznej ludności, głównie urzędników, a ubywało litewskojęzycznych katolików. We wspomnianym mieście i w promieniu $10 \mathrm{~km}$ od niego mieszkało tysiąc członków tej konfesji, natomiast pozostali - nawet w odległości do $30 \mathrm{~km}$. Dla tych osób utworzono cztery miejsca celebracji liturgicznych. Władze państwowe finansowały 11 punktów katechetycznych na terenie parafii. Wszystkie znajdowały się w odległości $10-25 \mathrm{~km}$ od Szyłokarczmy. Poza tym na jej obszarze przebywało 600 polskich jeńców wojennych oraz 400 polskich robotników ${ }^{29}$. Tegoż roku parafia ta zwracała się z prośbą o pomoc do Bonifatiuswerk w Paderborn, która dotyczyła spłaty zadłużenia wynikającego z nabycia samochodu ${ }^{30}$. Zresztą pod koniec 1939

\footnotetext{
23 AP, Teczka: Pogegen, ks. Marquardt do ks. Steinki, 31 I 1940.

24 Ibidem, ks. Steinki do ks. Schäfersa, 2 II 1940.

25 Ibidem, ks. Schäfers do kurii we Fromborku, 11 VII 1940.

26 Ibidem, ks. Bajertschus do kurii we Fromborku, 22 II 1941.

27 Ibidem, Frühjahr 1941.

${ }^{28}$ Ibidem, ks. Schäfers do parafii w Pogegen, 25 VII 1941.

29 AP, Teczka: Heydekrug, ks. Schacht do kurii we Fromborku, 25 III 1940.

30 Ibidem, ks. Steinki do ks. Schäfersa, 9 IV 1940.
} 
roku zabiegano w tej instytucji o dofinansowanie kupna tego rodzaju pojazdów do Wischwill i Pogegen. Tłumaczono, że są one niezbędne do prowadzenia duszpasterstwa na tym obszarze ${ }^{31}$.

W październiku 1940 roku wikariusz generalny diecezji warmińskiej ks. A. Marquardt przedłożył prośbę skierowaną do ministra spraw kościelnych w Berlinie o pomoc w pozyskaniu dokumentacji na temat Kościoła katolickiego w Okręgu Kłajpedy, która znajdowała się w kurii telszańskiej na Litwie. Wikariusz generalny informował przy tym, że w 1927 roku kuria diecezji warmińskiej wysłała na Litwę akta kościelne dotyczące tego obszaru. Negatywną odpowiedź uzasadniano w Telszach niespokojnym czasem toczącej się wojny ${ }^{32}$. Wysiłki dyplomatyczne podejmowane w tej sprawie w Stolicy Apostolskiej również nie przyniosły oczekiwanego efektu ${ }^{33}$.

\section{Finansowanie duchowieństwa}

W czasie inkorporacji Okręgu Kłajpedy do Rzeszy Niemieckiej na jego obszarze pracowali następujący księża katoliccy wywodzący się z diecezji warmińskiej: ks. proboszcz kanonik Albert Dannelautzki (Kłajpeda), ks. wikariusz Meinrad Stenzel (Kłajpeda), ks. wikariusz Paul Burger (Kłajpeda) oraz ks. proboszcz Franz Schacht (Szyłokarczma) ${ }^{34}$. Z kolei litewscy duchowni stali na czele niegdyś niemieckich placówek duszpasterskich w Robkojen, Pogegen i Wischwill ${ }^{35}$. Bezpośrednio po aneksji nastąpiły zmiany personalne wśród duchowieństwa udzielnej prałatury kłajpedzkiej. Litewski proboszcz Juozas Ruibys-Rodavičius z Robkojen został zmuszony do opuszczenia parafii w kwietniu 1939 roku. Na jego miejsce ustanowiono niemieckiego duszpasterza ks. Paula Bilitewskiego, który dopiero uczył się języka litewskiego ${ }^{36}$. Z kolei ks. M. Stenzela skierowano na studia specjalistyczne do Fryburga Bryzgowijskiego. Jego posadę 1 maja 1939 roku otrzymał na podstawie dekretu biskupa warmińskiego ks. P. Burger ${ }^{37}$.

Sporym zaskoczeniem dla lokalnego Kościoła była decyzja władz państwowych, zgodnie z którą od 1 maja 1939 roku wstrzymywano wypłaty pensji księżom udziel-

\footnotetext{
${ }^{31}$ AP, Teczka: Pogegen, ks. Steinki do ks. Schäfersa, 8 XI 1939.

${ }^{32}$ BAB, R 5101/21808, k. 139.

${ }^{33}$ Ibidem, k. 151.

${ }^{34}$ Ibidem, k. 54.

${ }^{35}$ Ibidem, k. 54.

${ }^{36}$ Ibidem, k. 56-56v.

${ }^{37}$ Ibidem, k. 56v. Biogramy wymienionych księży przytacza ks. Andrzej Kopiczko; zob. A. KoРісzко: Duchowieństwo katolickie diecezji warmińskiej w latach 1821-1945. Cz. 2: Słownik. Olsztyn
} 2003. 
nej prałatury kłajpedzkiej. U ministra spraw kościelnych interweniował wówczas wikariusz generalny diecezji warmińskiej ks. A. Marquardt. Zabiegał on o szybkie uregulowanie spraw uposażenia katolickiego duchowieństwa. Warto wspomnieć, że w tym czasie rozwiązano sporne kwestie dotyczące wynagrodzenia księży ewangelickich. Ksiądz A. Marquardt wskazywał przy tym, że duchowni prałatury, pochodzący z diecezji warmińskiej, należeli wcześniej do Prus. Posiadali zatem prawo do państwowej pensji ${ }^{38}$. Jego zdaniem, świadczenia te powinni również otrzymywać litewscy księża ze względu na dużą liczbę Litwinów zamieszkujących ten obszar ${ }^{39}$. Należy nadmienić, że od 1 kwietnia 1939 roku państwo nie płaciło pensji nowo zatrudnionemu proboszczowi w Robkojen ks. P. Bilitewskiemu ${ }^{40}$. Ksiądz dziekan A. Dannelautzki ubolewał z kolei, że wikariusze w Okręgu Kłajpedy musieli się sami utrzymywać ${ }^{11}$. Od 1 stycznia tego roku nie przekazywano również równowartości przysługujących dotychczas 100 litów na biuro dekanalne oraz tej samej kwoty przeznaczonej na urzędników kościelnych. Wstrzymano ponadto gwarantowane wcześniej fundusze na prace budowlane i remontowe udzielnej prałatury kłajpedzkiej. Dziekan kłajpedzki otrzymywał wcześniej od Dyrektoriatu Okręgu Kłajpedy do 300 litów rocznie za opiekę nad młodzieżąa ${ }^{42}$.

W celu rozwiązania spraw dotyczących uposażenia duchowieństwa katolickiego 19 maja 1939 roku udał się do Kłajpedy radca z Ministerstwa Spraw Kościelnych ${ }^{43}$. Udzielną prałaturę kłajpedzką reprezentował na tym spotkaniu ks. dziekan A. Dannelautzki ${ }^{44}$. Uzgodniono, że zobowiązania na rzecz Kościołów ewangelickiego i katolickiego za kwiecień 1939 roku zostaną wypłacone przez kończący swoją działalność Dyrektoriat, zaś świadczenia za maj tego roku miały przejąć Prusy ${ }^{45}$. Ostatecznie pensje duchowieństwa $\mathrm{w}$ udzielnej prałaturze kłajpedzkiej unormowano w rozporządzeniu państwowym z 6 lipca 1939 roku $^{46}$. Wówczas Ministerstwo Spraw Kościelnych poinformowało ks. dziekana A. Dannelautzkiego o wypłatach należności przeznaczonych dla proboszczów katolickich w powiecie kłajpedzkim. Inni księża (np. wikariusze) mieli otrzymywać pensję wyłącznie z funduszy kościelnych, stosownie do regulacji przyjętych w Prusach, wyjątek od tego stanowili duchowni, którym dopłatę do wynagrodzenia przydzielił Dyrektoriat Okręgu Kłajpedy. W takim przypadku ministerstwo było skłonne podtrzymać tę płatność ${ }^{47}$. Tego roku

\footnotetext{
38 BAB, R 5101/21808, k. 54.

39 Ibidem, k. 54-54v.

${ }^{40}$ Ibidem, k. 56v.

41 Ibidem, k. 56v.

42 Ibidem, k. 56v.

${ }^{43}$ Ibidem, k. 55.

${ }^{44}$ Ibidem, k. 71.

${ }^{45}$ Ibidem, k. 72.

46 Ibidem, k. 63.

${ }^{47}$ Ibidem, k. 76.
} 
obowiązujące wcześniej dodatki do uposażenia duchowieństwa zostały zastąpione dopłatami z niemieckiego skarbu państwa. Przekazano wówczas na rzecz ewangelickich księży 83544 marki, zaś na katolickich — 20900 marek $^{48}$.

Decyzja Dyrektoriatu Okręgu Kłajpedy z 17 marca 1938 roku, dotycząca wysokości uposażenia ks. dziekana A. Dannelautzkiego i ks. F. Schachta, nie była wiążąca dla Rzeszy Niemieckiej. Ministerstwo Spraw Kościelnych informowało ks. A. Dannelautzkiego, że jego pensja będzie naliczana zgodnie ze stawkami pruskimi. Zamierzano również obniżyć przyznaną mu państwową grupę uposażenia, podobnie zresztą jak ks. F. Schachtowi, do poziomu wynagrodzeń pruskich duchownych z podobnym stażem pracy ${ }^{49}$. Ksiądz A. Dannelautzki przekonywał jednak władze państwowe, że Rzesza Niemiecka jako prawny następca dawnego Okręgu Kłajpedy dziedziczy zobowiązania, które Dyrektoriat uprawomocnił w podjętej przez siebie decyzji. W związku z tym duchowny domagał się przynależności do tej grupy uposażenia, w której znaleźli się także dyrektorzy sądów czy wyżsi stopniem nauczyciele szkół średnich. Podstawowa pensja w grupie XII w Okręgu Kłajpedy, do której należeli wspomniani księża, na rok przed wybuchem wojny wynosiła 1340 litów oraz 115 litów dopłaty mieszkaniowej. W trakcie tego roku ks. A. Dannelautzki otrzymał jednak tylko 866 litów, czyli 346,40 marek $^{50}$.

Ministerstwo Spraw Kościelnych kwestionowało argumentację ks. A. Dannelautzkiego. Wprawdzie Dyrektoriat przyznał mu XII grupę uposażenia, jednak na podstawie ustawy dotyczącej budżetu Okręgu Kłajpedy z 14 sierpnia 1933 roku, stanowiącej o uposażeniu administracji komunalnej, wypłacano mu jedynie $63 \%$ wskazanej kwoty, czyli 844,20 lity, co dawało 337,68 marek miesięcznie ${ }^{51}$. W swoim liście z 13 grudnia 1940 roku ks. A. Dannelautzki wskazywał, że za pośrednictwem kurii biskupiej we Fromborku otrzymywał z niemieckiego Funduszu Dopłat do Wynagrodzenia Proboszczowskiego (Pfarrbesoldungsfonds) 292 marki miesięcznie. Z informacji zaprezentowanych przez zarząd kościelny w Kłajpedzie wynikało, że przychody z posługi duszpasterskiej tego księdza wynosiły 420 marek rocznie, zaś z podatku kościelnego przekazywano mu 300 marek. Jego roczny dochód z parafii opiewał zatem na 720 marek, co dawało miesięcznie 60 marek. Sumując wszystkie przekazywane mu donacje z tytułu wynagrodzenia, zarabiał on, poza nieodpłatnym korzystaniem z mieszkania, 352 marki miesięcznie. Kwota ta była zatem wyższa niż dodatek wypłacany mu przez Dyrektoriat Okręgu Kłajpedy. W podobnej sytuacji znajdował się również ks. proboszcz F. Schacht ${ }^{52}$. Pod koniec grudnia 1939 roku Ministerstwo Spraw Wewnętrznych wypowiedziało się przeciwko podtrzy-

\footnotetext{
48 Ibidem, k. 180.

49 Ibidem, k. 82-82v.

50 Ibidem, k. 86.

51 Ibidem, k. 164.

52 Ibidem, k. 164v.
} 
maniu decyzji Dyrektoriatu Okręgu Kłajpedy o przyznaniu tym duchownym XII grupy uposażenia ${ }^{53}$. Mieli oni zatem otrzymywać dopłaty do pensji jak inni księża $\mathrm{w}$ Prusach ${ }^{54}$. W nieco innej sytuacji znajdowali się duchowni, którzy pracowali w katolickich placówkach duszpasterskich nieposiadających statusu pełnoprawnych parafii. W udzielnej prałaturze kłajpedzkiej zaliczano do nich Pogegen i Wischwill. Postulowaną wysokość uposażenia tamtejszych duszpasterzy określały władze diecezji warmińskiej ${ }^{55}$. Zatrudnionemu w Pogegen ks. F. Bajertschusowi (lit. Pranciškus Bajerčius) wysługę lat liczono od 1 czerwca 1920 roku. Z iura stole i innych donacji tej placówki uzyskał on w 1939 roku 340 marek. Od tej sumy odliczano koszty związane z wyjazdami duszpasterskimi, czyli 150 marek. W sumie z parafii pobierał on 190 marek. Rok wcześniej postulowana wartość podatku kościelnego w tej placówce wynosiła 500 marek, natomiast rzeczywiste wpływy - jedynie 100 marek. Na rzecz wynagrodzenia tego księdza przeznaczono z tej kwoty 15 marek $^{56}$. Z kolei w parafii misyjnej w Wischwill wysługę lat naliczano tamtejszemu duszpasterzowi ks. Josefowi Lechaviciusowi (lit. Juozas Lechavičius) od 1 lipca 1932 roku. W 1939 roku z użytkowania gruntów parafialnych o wielkości 12 hektarów 49 arów i 6 metrów kwadratowych (z czego 2 hektary 65 arów i 89 metrów kwadratowych były wyłączone z uprawy) pobierał on 500 marek, natomiast $\mathrm{z}$ iura stole i innych donacji parafialnych -470 marek. Od tej sumy odliczano 200 marek za dojazdy duszpasterskie. Jego przychody sięgały zatem 770 marek. Rok wcześniej postulowana kwota z podatku kościelnego opiewała na 800 marek, a realne wpływy z tego źródła - jedynie na 160 marek. $Z$ tej sumy wypłacano duszpasterzowi zaledwie 24 marki ${ }^{57}$.

W 1939 roku przychody duszpasterzy w udzielnej prałaturze kłajpedzkiej były dość niskie. W związku z tym zabiegano u władz Rzeszy Niemieckiej o ich zwiększenie, co ilustruje tabela 1.

Władze diecezji warmińskiej postulowały, aby Rzesza Niemiecka zaaprobowała najwyższe wynagrodzenie dla proboszczów z Kłajpedy i Szyłokarczmy (6554 marek). Najmniejsza postawa uposażenia przysługiwałaby proboszczowi z parafii misyjnej w Wischwill (3356 marek). Największe wynagrodzenie proboszczowi zapewniała w tym czasie parafia w Robkojen (2009 marek łącznie z podatkiem kościelnym), a najmniejsze - w Pogegen (205 marek). Najwyższą dopłatę z funduszy państwowych otrzymywał proboszcz z Kłajpedy (346,40 marek), a najniższą - proboszcz z Wischwill (155,20 marek). Zabiegano zatem, aby beneficjentem najwyższej dopłaty ze skarbu państwa był proboszcz z Szyłokarczmy (miała ona wynosić 5948 marek),

\footnotetext{
${ }^{53}$ Ibidem, k. 89.

${ }^{54}$ Ibidem, k. 92.

${ }^{55}$ Ibidem, k. 93.

${ }^{56}$ Ibidem, k. 96-97v.

${ }^{57}$ Ibidem, k. 98-99v.
} 
następnie proboszcz z Kłajpedy (5834 marki). Najmniej otrzymywałby z tego źródła proboszcz z Robkojen (jedynie 1650 marek).

Tabela 1

Zestawienie postulowanej wysokości uposażenia proboszczów udzielnej prałatury kłajpedzkiej w 1939 roku

\begin{tabular}{|l|c|c|c|c|c|}
\hline $\begin{array}{c}\text { Katolicka placówka } \\
\text { duszpasterska }\end{array}$ & $\begin{array}{c}\text { Postulowana } \\
\text { roczna wysokość } \\
\text { uposażenia } \\
\text { proboszcza } \\
\text { [w markach] }\end{array}$ & $\begin{array}{c}\text { Przychody } \\
\text { proboszczowskie } \\
\text { z parafii } \\
\text { [w markach] }\end{array}$ & $\begin{array}{c}\text { Przychody } \\
\text { z podatku } \\
\text { kościelnego } \\
\text { [w markach] }\end{array}$ & $\begin{array}{c}\text { Brakująca kwota } \\
\text { w odniesieniu } \\
\text { do postulowanej } \\
\text { wysokości } \\
\text { uposażenia } \\
\text { [w markach] }\end{array}$ & $\begin{array}{c}\text { Dotychczas } \\
\text { wypłacana } \\
\text { miesięczna do- } \\
\text { płata z funduszy } \\
\text { państwowych } \\
\text { [w markach] }\end{array}$ \\
\hline Kłajpeda & 6554,00 & 420,00 & 300,00 & 5834,00 & 346,40 \\
\hline Pogegen & 3581,00 & 190,00 & 15,00 & 3376,00 & 256,80 \\
\hline Robkojen & 3659,00 & 1964,00 & 45,00 & 1650,00 & 166,00 \\
\hline Szyłokarczma & 6554,00 & 579,00 & 27,00 & 5948,00 & 279,20 \\
\hline Wischwill & 3356,00 & 770,00 & 24,00 & 2562,00 & 155,20 \\
\hline \multicolumn{1}{|c|}{ Ogółem } & 23704,00 & 3923,00 & 411,00 & 19370,00 & 1203,00 \\
\hline
\end{tabular}

Źródło: BAB, R 5101/21808, k. 95.

W 1939 roku w udzielnej prałaturze kłajpedzkiej wikariusze otrzymywali ustalone przez diecezję warmińską pensje wraz z nieodpłatnym użytkowaniem mieszkania. Jedynie wikariusz Johann Maknys nie korzystał z darmowego zakwaterowania ${ }^{58}$. Oczywiście domagano się ich dofinansowania z funduszy państwowych.

Z tabeli 2 wynika, że kłajpedzcy wikariusze zarabiali 330 marek rocznie, natomiast szyłokarczemski - 320. Postulowano, aby władze państwowe zagwarantowały ks. J. Juknewitschowi i J. Maknysowi roczne uposażenie o wartości 2969 marek. Dwóch pozostałych wikariuszy, czyli ks. P. Burger i J. Staschkewitsch, miałoby zarabiać nieco mniej - 2835 marek. Biorąc pod uwagę zaproponowaną podstawę uposażenia, władze państwowe musiałyby najwięcej wyasygnować na rzecz wikariuszy kłajpedzkich ks. J. Juknewitscha i J. Maknysa, bo aż 2639 marek, zaś najmniej - na ks. P. Burgera (2505 marek). Warto nadmienić, że ks. J. Juknewitsch, J. Maknys i P. Burger z Kłajpedy na poczet wynagrodzenia (czyli wyróżnione w tabeli 2 przychody wikariuszowskie) pobierali po 60 marek z iura stole i po 270 marek ze stypendiów mszalnych ${ }^{59}$, natomiast ks. J. Staschkewitsch z Szyłokarczmy - 50 marek $\mathrm{z}$ iura stole i 270 ze stypendiów mszalnych ${ }^{60}$.

\footnotetext{
${ }^{58}$ Ibidem, k. 93.

59 Ibidem, k. 102, 103, 104.

60 Ibidem, k. 105.
} 
Zestawienie postulowanej wysokości uposażenia wikariuszy w udzielnej prałaturze kłajpedzkiej w 1939 roku

\begin{tabular}{|l|l|c|c|c|}
\hline Imię i nazwisko wikariusza & Parafia & $\begin{array}{c}\text { Postulowana } \\
\text { roczna wysokość } \\
\text { uposażenia } \\
\text { wikariusza } \\
\text { [w markach] }\end{array}$ & $\begin{array}{c}\text { Przychody } \\
\text { wikariuszowskie } \\
\text { z parafii } \\
\text { [w markach] }\end{array}$ & $\begin{array}{c}\text { Brakująca kwota } \\
\text { w odniesieniu } \\
\text { do postulowanej } \\
\text { wysokości } \\
\text { uposażenia } \\
\text { [w markach] }\end{array}$ \\
\hline Josef Juknewitsch & Kłajpeda & 2969,00 & 330,00 & 2639,00 \\
\hline Johann Maknys & Kłajpeda & 2969,00 & 330,00 & 2639,00 \\
\hline Paul Burger & Kłajpeda & 2835,00 & 330,00 & 2505,00 \\
\hline Johann Staschkewitsch & Szyłokarczma & 2835,00 & 320,00 & 2515,00 \\
\hline
\end{tabular}

Źródło: BAB, R 5101/21808, k. 100-101.

W marcu 1940 roku Ministerstwo Spraw Kościelnych zadecydowało o podwyżce dopłaty do uposażenia katolickich księży z udzielnej prałatury kłajpedzkiej. Dotyczyła ona nie tylko bieżących wynagrodzeń, ale również wcześniejszych pensji. Od maja do grudnia 1939 roku wypłacano ogółem tamtejszym duchownym 1980 marek miesięcznie. Kwotę tę podwyższono o 327 marek. W sumie miesięczna dotacja ze skarbu państwa wynosiła 2307 marek. Nieco mniej pieniędzy przyznano w pierwszym kwartale 1940 roku. Miesięczną kwotę bazową 1980 marek zwiększono jedynie o 287 marek. Władze państwowe przekazywały zatem na pensje tej grupy społecznej 2267 marek miesięcznie ${ }^{61}$.

Jak wynika z tabeli 3, największe dopłaty do uposażenia władze państwowe przyznały proboszczowi z Szyłokarczmy ks. F. Schachtowi (496 marek) oraz proboszczowi z Kłajpedy ks. A. Dannelautzkiemu (486 marek). Najmniejsze świadczenia otrzymał proboszcz misyjny z Wischwill ks. J. Lechavicius (155 marek) i wikariusz z Szyłokarczmy ks. J. Staschkewitsch (140 marek). Poza uposażeniem katolickich duchownych władze państwowe podwyższyły również dodatek za prowadzenie biura dekanalnego o 40 marek $^{62}$.

31 marca 1940 roku obniżono jednak państwowe dopłaty do uposażenia księży prałatury kłajpedzkiej. Prawdopodobnie dostosowano je wówczas do należności pobieranych przez księży $\mathrm{w}$ innych częściach prowincji. W związku z tym pensja księży kłajpedzkich uległa zmniejszeniu o 28\%. Należy także zaznaczyć, że kwota przekazywana przez państwo na rzecz diecezji warmińskiej z tytułu dopłat do uposażenia proboszczowskiego, której beneficjentami byli również księża udzielnej prałatury kłajpedzkiej, nie uległa podwyższeniu po włączeniu Okręgu Kłajpedy do

\footnotetext{
61 Ibidem, k. 106.
}

62 Ibidem, k. 107. 
Rzeszy Niemieckiej. Wikariusz generalny diecezji warmińskiej ks. A. Marquardt zabiegał zatem u władz państwowych o przyznanie nadzwyczajnych świadczeń na rzecz tej grupy księży. Uzasadniał przy tym, że ich finansowanie z państwowego Funduszu Dopłat do Wynagrodzenia Proboszczowskiego spowoduje zmniejszenie pensji innym księżom diecezji warmińskiej. Wikariusz generalny konkludował przy tym, że księża prałatury kłajpedzkiej w sensie prawnym nie należeli do wspomnianej diecezji ${ }^{63}$. Warto jeszcze przytoczyć szacunkowe roczne wpływy z iura stole, które podała kuria biskupia we Fromborku w połowie 1940 roku. W parafii Kłajpeda spodziewano się 450 marek z tego źródła, w Robkojen - 502 marki, zaś w Szyłokarczmie - 200 marek $^{64}$.

Tabela 3

Dopłata do uposażenia katolickich duchownych w udzielnej prałaturze kłajpedzkiej na podstawie decyzji z 2 marca $1940 \mathrm{r}$.

\begin{tabular}{|l|l|c|}
\hline \multicolumn{1}{|c|}{ Imię i nazwisko duchownego ${ }^{\text {a) }}$} & \multicolumn{1}{|c|}{ Placówka duszpasterska } & $\begin{array}{r}\text { Wysokość dopłaty } \\
\text { do uposażenia } \\
\text { [w markach] }\end{array}$ \\
\hline Albert Dannelautzki & Kłajpeda & 486,00 \\
\hline Franz Schacht & Szyłokarczma & 496,00 \\
\hline Paul Bilitewski & Robkojen & 138,00 \\
\hline Franz Bajertschus & Pogegen & 257,00 \\
\hline Josef Lechavicius & Wischwill & 155,00 \\
\hline Josef Juknewitsch (wikariusz) & Kłajpeda & 169,00 \\
\hline Johann Maknys (wikariusz) & Kłajpeda & 180,00 \\
\hline Paul Burger (wikariusz) & Kłajpeda & 206,00 \\
\hline Johann Staschkewitsch (wikariusz) & Szyłokarczma & 140,00 \\
\hline & & Suma \\
\hline
\end{tabular}

a) Zachowano kolejność ze źródła.

Źródło: BAB, R 5101/21808, k. 106v.

Ksiądz wikariusz J. Staschkewitsch z Szyłokarczmy otrzymywał dopłatę do pensji tylko do końca maja 1941 roku, czyli do czasu wyjazdu z parafii ${ }^{65}$. Z kolei ks. J. Maknys, również litewski wikariusz, pracujący w parafii w Kłajpedzie, został pozbawiony tego urzędu 16 kwietnia 1941 roku. Po czterech dniach opuścił on tę parafię i miasto. Jak pisał ks. A. Dannelautzki, nie zadał on sobie trudu, aby

\footnotetext{
${ }^{63}$ Ibidem, k. 163, 180v.

64 Ibidem, k. 137.

65 Ibidem, k. 106v, 177.
} 
nauczyć się gruntownie języka niemieckiego. Jego miejsce zajął o. Karl Fulst SJ. Przez 10 wcześniejszych lat pracował w gimnazjum w Kownie ${ }^{66}$. Obszar Nadniemna znał dość dobrze, ponieważ przebywał tu na zastępstwach, szczególnie w czasie ferii szkolnych. Cieszył się również dobrymi referencjami niemieckiego poselstwa w Kownie ${ }^{67}$. Władze państwowe nie zgodziły się jednak na przyznanie o. K. Fulstowi dopłaty do wynagrodzenia ${ }^{68}$. We wrześniu 1941 roku kuria diecezjalna we Fromborku informowała, że zastępca wikariusza w Kłajpedzie został powołany do wojska. Ze względu na odczuwane w diecezji braki personalne biskup warmiński nie nominował na jego miejsce innej osoby ${ }^{69}$. Wprawdzie tego miesiąca ordynariusz ponownie zwrócił się do Ministerstwa Spraw Duchownych z prośbą o zatrudnienie w diecezji dwóch litewskich duszpasterzy, ks. Wiktora Garbukasa i ks. Witolda Ziuraitisa-Schurata, ale otrzymał odmowną odpowied $z^{70}$.

27 lutego 1941 roku Ministerstwo Spraw Kościelnych utrzymało na bieżący rok dopłaty do uposażenia wikariuszy w prałaturze kłajpedzkiej. Na ten cel, wzorem poprzedniego roku, zarezerwowano $13284 \mathrm{marki}^{71}$. W roku rozrachunkowym 1942 na rzecz tej grupy duchownych przeznaczono już tylko 9444 marki ${ }^{72}$. Tę samą kwotę wyasygnowano także w kolejnych dwóch latach ${ }^{73}$.

Nieprzychylny stosunek Rzeszy Niemieckiej do Kościoła katolickiego znalazł odzwierciedlenie m.in. w przypadku ks. P. Bilitewskiego. Po niemieckiej aneksji Okręgu Kłajpedy duchowny ten zadeklarował chęć objęcia urzędu proboszczowskiego w Robkojen. Jak się sam wyraził, przejął miejsce po proboszczu, który daremnie próbował lituanizować niemieckich mieszkańców tego obszaru. W listopadzie 1943 roku zarzucał on ks. A. Dannelautzkiemu (pełniącemu w czasie 22 marca-16 lipca 1939 roku urząd administratora udzielnej prałatury kłajpedzkiej), że utrudniał mu posługę duszpasterską. Do czasu przekazania pieczy nad udzielną prałaturą kłajpedzką biskupowi warmińskiemu, dziekan ten miał faworyzować i wspierać duchowieństwo litewskie. O ile inkardynacja litewskiego duchowieństwa do prałatury kłajpedzkiej przebiegła nadzwyczaj szybko, o tyle ks. P. Bilitewski musiał odbyć trzyletni czas próby. Duszpasterz ten uważał ponadto, że w przeciwieństwie do litewskich księży, nie nadano mu tytułu proboszcza, degradując go tym samym do funkcji komendariusza. Ponadto żądano od niego przedłożenia egzaminów proboszczowskich, podczas gdy wymagań tych nie stosowano

${ }^{66}$ Ibidem, k. 169, 170.

${ }^{67}$ Ibidem, k. $169 \mathrm{v}$.

${ }^{68}$ Ibidem, k. 171.

${ }^{69}$ AP, Teczka: Memel, ks. Marquardt do Stowarzyszenia św. Bonifacego w Paderborn, 18 IX 1941.

70 A. Корісzко: Duchowieństwo katolickie diecezji warmińskiej w latach 1821-1945. Cz. 1..., s. 250.

${ }^{71}$ BAB, R 5101/21808, k. 168.

${ }^{72}$ Ibidem, k. 180v.

${ }^{73}$ Ibidem, k. 195v-196. 
wobec Litwinów ${ }^{74}$. Warto zaznaczyć, że ks. P. Bilitewski pobierał z kasy państwowej dopłatę do uposażenia, którą przyznawano proboszczom. Wynikało to zresztą z zarządzenia biskupa warmińskiego z 1 lutego i 1 kwietnia 1940 roku. Gdyby ks. P. Bilitewski nie był uznany w diecezji warmińskiej za proboszcza, jej władze musiałyby zwrócić do skarbu państwa wypłacone mu należności ${ }^{75}$. W rzeczywistości był on administratorem w Robkojen od 7 kwietnia 1939 roku. Jego funkcja, jak stwierdzano w piśmie kurii telszańskiej z 28 września 1939 roku, dotyczyła parochia movibiles, czyli proboszczów, których można usunąć z parafii. Pełniony przez niego urząd potwierdził zresztą wikariusz generalny diecezji telszańskiej 16 listopada 1939 roku. Obejmując go, ks. P. Bilitewski nie został jeszcze zwolniony z przynależności do zakonu jezuitów. Stosowny dekret w tej sprawie wystawiono dopiero 22 czerwca 1939 roku. Wcześniej zatem nie mógł przejąć pełnoprawnego administrowania parafią. Władze diecezjalne nie zwolniły go ponadto z egzaminów proboszczowskich $^{76}$.

Ostatecznie Ministerstwo Spraw Kościelnych zadecydowało, że ks. P. Bilitewski, zarządzający parafią na podstawie polecenia władz kościelnych, a nie nominacji proboszczowskiej, nie może pobierać państwowych dopłat do uposażenia, które przysługiwały proboszczom. $Z$ tego względu 26 stycznia 1944 roku zobowiązano diecezję warmińską do zwrotu należności wypłaconych przez władze państwowe temu księdzu od 1 maja 1939 roku. Kwota ta miała zostać powiększona o czteroprocentowe odsetki ${ }^{77}$. Diecezja warmińska 11 lutego 1944 roku odwoływała się od tej decyzji, wskazując, że ks. P. Bilitewski na urząd proboszczowski w Robkojen został ustanowiony przez biskupa telszańskiego już w kwietniu 1939 roku. Dodatek do wynagrodzenia otrzymywał zatem nawet od Dyrektoriatu Okręgu Kłajpedy $^{78}$. Ostatecznie 9 marca 1944 roku władze państwowe odstąpiły od konieczności zwrotu tych pieniędzy, ponieważ Fundusz Dopłat do Wynagrodzenia Proboszczowskiego był przekazywany diecezji warmińskiej w stałej kwocie. Wyłączenie z niego poszczególnych duchownych nie uszczuplało jego wartości ${ }^{79}$. Ministerstwo Spraw Kościelnych zażądało jedynie natychmiastowego odebrania ks. P. Bilitewskiemu prawa dotyczącego państwowej dopłaty do wynagrodzenia ${ }^{80}$. Duchowny ten 1 marca 1944 roku wycofał również swoje oskarżenia względem ks. dziekana A. Dannelautzkiego ${ }^{81}$.

\footnotetext{
74 Ibidem, k. 183.

75 Ibidem, k. 183v.

${ }^{76}$ Ibidem, k. 187; A. KopICzko: Duchowieństwo katolickie diecezji warmińskiej w latach 1821-

1945. Cz. 1..., s. 251.

77 BAB, R 5101/21808, k. 193-194.

78 Ibidem, k. 197.

79 Ibidem, k. 198-198v.

80 Ibidem, k. 199.

81 Ibidem, k. 201.
} 


\section{Zakończenie}

Wcielenie Okręgu Kłajpedy do Rzeszy Niemieckiej nie przyniosło udzielnej prałaturze kłajpedzkiej wymiernych korzyści. Stolica Apostolska utrzymała jej status, mianując jednakże administratorem apostolskim tego obszaru biskupa warmińskiego. Władze hitlerowskie, nieprzychylne Kościołowi katolickiemu, nie zniwelowały trudnej sytuacji materialnej tamtejszych placówek duszpasterskich. Nie podjęly także satysfakcjonujących decyzji w sprawie wynagrodzenia duchowieństwa katolickiego. Zarówno tamtejsze placówki duszpasterskie, jak i księża otrzymywali wsparcie materialne spoza prałatury. Pomoc okazała zwłaszcza diecezja warmińska oraz instytucje działające na rzecz diaspory, np. Bonifatiuswerk.

W październiku 1944 roku Armia Czerwona przekroczyła północne granice Prus Wschodnich, zajmując Szyłokarczmę oraz pozostałe miejscowości na południe od Kłajpedy. Zacięte walki o to miasto portowe trwały z kolei do 28 stycznia 1945 roku. Zdobyte wówczas historyczne obszary kraju kłajpedzkiego weszły w skład Litewskiej Socjalistycznej Republiki Radzieckiej ${ }^{82}$. Likwidacja udzielnej prałatury kłajpedzkiej została tym samym z góry przesądzona.

\section{Bibliografia}

Kopiczko A.: Die katholische Kirche in Memelland (1923-1939). „Acta Historica Universitatis Klaipedensis" 2015, 30, s. 101-125.

Kopiczкo A.: Duchowieństwo katolickie diecezji warmińskiej w latach 1821-1945. Cz. 1: Studium prozopograficzne. Olsztyn 2004.

KopIczko A.: Duchowieństwo katolickie diecezji warmińskiej w latach 1821-1945. Cz. 2: Słownik. Olsztyn 2003.

Łossowski P.: Kłajpeda kontra Memel. Problem Kłajpedy w latach 1918-1939-1945. Warszawa 2007.

Mikulicz S.: Kłajpeda w polityce europejskiej 1918-1939. Warszawa 1976.

Ochmański J.: Historia Litwy. Wrocław 1982.

SAKson A.: Kraj Kłajpedzki. Zmiany ludnościowe 1945-1950. „Przegląd Zachodni” 2007, 3, s. 105125.

Streikus A.: Die Integration der memelländischen Katholiken in die Kirchenprovinz Litauen 19261939. „Annaberger Annalen” 2013, 21, s. 100-127.

TAUSBER J.: Das Memelgebiet (1919-1945) in der deutschen und litauischen Historiografie nach 1945. „Nordost-Archiv. Zeitschrift für Regionalgeschichte” (Neue Folge) 2001, 10, s. 11—44.

82 A. Sakson: Kraj Kłajpedzki. Zmiany ludnościowe 1945-1950. „Przegląd Zachodni” 2007, 3, s. 106 . 


\section{The sovereign prelature of Klaipeda after annexing the Klaipeda Region by the Third Reich in 1939}

Summary

In the year 1925 the Kleipeda Region was incorporated into Lithuania. A year later, Pope Pius XI erected in this region the sovereign prelature of Klaipeda with the Telšiai bishop at its helm. In March 1939 Germany coerced Lithuania into signing a pact according to which the Klaipeda Region became a part of the Third Reich. Quite promptly, the bishop of Telšiai handed the administrative matters of the prelature to Fr. Dean Albert Dannelautzki of Kleipeda. However, on 10 June 1939 the Holy See entrusted the prelature to the Bishop of Warmia Maksymilian Kaller, who was nominated as an apostolic administrator. The lack of material resources was detrimental for the prelature's activity. For instance, no renovations in churches and adjacent building were carried out in that time. Local pastoral facilities took advantage of financial aid offered by the diocese of Warmia and organizations supporting pastoral activity of diaspora, mainly Bonifatiuswerk (Das Bonifatiuswerk der deutschen Katholiken) in Paderborn.

Key words: Catholic Church in the Third Reich, Lithuania, Klaipeda Region, East Prussia, sovereign prelature of Klaipeda 